\title{
Where has the water come from?
}

\section{Editorial "water history"}

\author{
Johann Tempelhoff · Heather Hoag • Maurits Ertsen • Ellen Arnold • \\ Matthew Bender · Kate Berry · Carol Fort • David Pietz • \\ Muchaparara Musemwa · Masayoshi Nakawo · Jason Ur • \\ Petra van Dam · Martin Melosi · Verena Winiwarter • \\ Tony Wilkinson
}

Published online: 1 July 2009

(C) The Author(s) 2009. This article is published with open access at Springerlink.com

\section{Introduction}

Another new journal, and one on water history? Why is one necessary especially at this point of time? The answer to these questions is twofold. First, the relationship between water and humanity has always been inextricably intertwined throughout history, but water has been and is likely to continue to be one of the most pressing environmental and resource concerns. Studying water history enhances our understanding about the nexus between the human and physical worlds within specific temporal and spatial settings. As problems of water availability and competition are becoming ever more acute, examples of

J. Tempelhoff

North-West University, Vanderbijlpark, South Africa

H. Hoag

University of San Francisco, San Francisco, USA

M. Ertsen $(\bowtie)$

Delft University of Technology, Delft, The Netherlands

e-mail: m.w.ertsen@tudelft.nl

E. Arnold

Macalester College, St. Paul, USA

M. Bender

The College of New Jersey, Ewing, USA

K. Berry

University of Nevada, Reno, USA

C. Fort

Flinders University, Adelaide, Australia 
past water management and social relations to water use have become increasingly relevant to our understanding of future scenarios of water use. Second, recently many research findings demonstrating high-quality scholarship on water history have been published in diverse journals. While the recent publication of some of these articles focused on water history suggests that the field is expanding in both size and scope, it also shows that the field is still lacking a central point of focus. The interdisciplinary field of water history will be able to develop further through a medium solely dedicated to publishing the best of this new scholarship.

The value human societies place on water-for life, domestic use, economic production, and spirituality - has led all civilizations to manipulate water flows (Adams 1992; Boomgaard 2007; Collins 1990; Diaz and Morehouse 2003; Donahue and Johnston 1998; Gill 2000; Hundley 1992; Lansing 1991; Lucero and Fash 2006; Marcus and Stanish 2005; Magnusson 2001; Miller 2001; Pietz 2002; Rortajada 2000; Scarborough 2003; Steinberg 1991; Ward 2003; Worster 1985). One of the earliest, if not the earliest, textually documented war was fought between the Mesopotamian city-states of Lagash and Umma over a canal and its associated irrigated fields (Cooper 1983). Whether it is for food production, drinking water, sanitation, transportation, electricity generation, or other material needs, access to and use of water has played defining roles in the development of human institutions.

Yet water, be it manipulated by human agency or not, is not necessary beneficial. Large flooding can be very disruptive (Bankoff 2003), as the recent Asian tsunami and the flooding of New Orleans have proven once more. Besides, the human interference with (ground)water can lead to very unexpected and unwanted consequences. Soils saturated with salts due to irrigation, desertification, and broken dams caused havoc at a grand scale (Reisner 1986). The deep-felt emotions by victims and onlookers, the long-lasting material damage, and ultimately, the impetus for technological improvement deserve attention within water history.

D. Pietz

University of Washington, Pullman, USA

M. Musemwa

University of the Witwatersrand, Johannesburg, South Africa

M. Nakawo

National Institutes for the Humanities, Tokyo, Japan

J. Ur

Harvard University, Cambridge, USA

P. van Dam

Vrije Universiteit Amsterdam, Amsterdam, The Netherlands

M. Melosi

University of Houston, Houston, USA

V. Winiwarter

Klagenfurt University, Klagenfurt, Austria

T. Wilkinson

Durham University, Durham, UK 
Humans attribute a variety of meanings to water, and this differs according to culture and time. Connotations of water such as purity and transition are widespread. Classic examples are the preference of Hindu people to die near the river Ganges and have their ashes put in the river, the ritual of baptism which symbolizes the conversion to Christianity, and the body washing of Muslims to clean before praying.

The combination of material, cultural, and religious uses and meanings of water has shaped water systems and has emphasized the intrinsic proximity of the natural and human worlds. One of the central aims of water history is to explore this interrelatedness, thus surfacing the changing relationship between people and water over time. In this relationship, the material properties of water do matter. Composed of two atoms, the water molecule has both peculiar and highly useful chemical properties. As the chemist and former editor of Nature magazine Philip Ball explains:

Water's strangeness resides almost wholly in its hydrogen-bonded character. While it is not by any means the only molecule that can form hydrogen bonds, no other has just the right shape to allow the network to extend throughout all space: the crucial twist of the hips to impersonate water opens up the third dimension. The hydrogen bonds impose structural constraints that are most unusual for a liquid, and these in turn affect the physical properties such as density, heat capacity and heat conductance - as well as the way that water accommodates dissolved molecules [...]" (Ball 1999, p. 168).

In addition to its physical properties, the movement of water through the larger hydrological cycle (and through that the global energy cycle as well) adds a unique chronological element. Water in its various forms is in constant motion through time and space-it evaporates from the oceans, falls to the ground, is absorbed into the soil or stored in frozen (and melting) icecaps, and eventually returns to the oceans. The timescale for each droplet of water can differ greatly. Groundwater can be thousands of years old; today's rain may travel only a day between ocean and land. This temporal property of water connects it directly to human action. The water we experience today most likely has come into contact with humans before.

It seems that the attention for the history of water in the scholarly field is rising. Since 2008, at least three academic journals have devoted issues to water. Technology and Culture's July 2008 issue showcased the thematic and geographical breadth of the field: from sanitation in England and Scandinavia and tank irrigation in India and Indonesia to the cultural dynamics of water supply in Istanbul. The January 2009 special issue of the scientific journal Physics and Chemistry of the Earth focused on contemporary issues of water management and the growth of global institutions concerned with water, while the March 2009 issue of World Archaeology explored the relationship between water control and state formation as well as the meanings and functions of water across time and space.

This recent spate of research on water confirms that water history has developed into a vibrant historical subfield-one that incorporates and contributes to environmental history, urban history, and the history of technology and landscape. Furthermore, the centrality of water to human and natural history offers the opportunity for historians to collaborate with and learn from colleagues in archaeology, anthropology, the sciences, engineering, geography, and development studies, to name but the most obvious. This new journal on water history will enable the academic community to develop a cumulative body of knowledge that will define the identity of this sub-discipline and create space for interdisciplinary scholarly engagement (compare with Tempelhoff 2005). 


\section{The paradox of an interdisciplinary field with a discipline}

Water history brings together the human and physical worlds within specific temporal and spatial settings. These settings influence each other, both hydrologically and culturally. For example, the practice of draining water from the western part of the Netherlands, begun several hundred years ago, structures material and social conditions today with its numerous dikes, dams, and sluices, specialized water taxes and institutions. One of the ironies of history was the perpetual (and costly) subsiding of the peat soils in what became the commercial center of the country (Van Dam 2000; De Bruin and Schultz 2003). Thus, a series of events which occurred within a discrete period of time continue to partially determine the developments in Dutch society. Since water has structured the development of human communities throughout the world, its study contributes to our understanding of economic, political, social, and environmental history, the history of science, medicine, technology, environmental sciences, and geography. As such, water history touches upon and informs many fields of study across the humanities, social sciences, and sciences, and incorporates their methods and lessons.

Through their diverse training, formulation of research questions, theoretical approaches, methods of analysis, and use of sources, water historians are taking up the call to "transcend disciplinary boundaries [...]" (Sewell 2005, p. 3) while remaining true to the tenets of the historical discipline: "its careful use of archival or 'primary' sources, its insistence on meticulously accurate chronology, and its mastery of narrative" (Sewell 2005, p. 3). Water History aims to publish original research that complements, critiques, and revises the methodological and theoretical approaches generated by a variety of disciplines to build empirical and interpretive frameworks to understand the ever-changing world of water.

\section{The tide mill as a symbol}

When developing the first issue, the cover photo was discussed among the editors and advisors. What would be a suitable picture for the first issue of a new journal? What statement should we make? Would an aqueduct be a powerful symbol of the intricate relationship between water economies, technologies, and cultures, or would that image be a cliché, perhaps simply a Eurocentric image? Would a work of art be a good choice, for example, Aboriginal water art? Or would that be too inaccessible? When developing these ideas, typical artifacts generated strong associations and meanings. A single artifact also does not mean much without a context.

As the reader will have noted, the cover of this first issue has an image of a tide mill from l'île de Bréhat, constructed in the first half of the seventeenth century.

Often referred to in the past as 'salt mills', 'salt water mills' or 'sea mills', tide mills worked on the simple principle of impounding water at high tide behind a barrier (or dam) on the foreshore. As the tide rose, water entered a tidal millpond through a sluice gate in the dam which closed at high water. When the tide dropped sufficiently to leave the waterwheel free of the water that would impede its rotation, the impounded water in the millpond was released to turn the wheel to allow milling to start. Milling ceased when the rising tide reached the waterwheel again or when the millpond was empty. (McErlean and Crothers 2008, p. 16). 
Obviously, tide mills could only operate when certain physical conditions in the natural environment were present. The ideal location of a tide mill is on coasts with sufficient tidal range, preferably with small inlets or estuaries that can be easily blocked with a dam to provide the mill with its pond. If one looks on the map of Europe to find locations of tide mills it becomes clear that concentrations of mills are found in southeastern England, the French west coast (proof is on the cover!), north and southwest Spain, and southwest Portugal (McErlean and Crothers 2008; Minchinton 1979; Charlier et al 2004). In Belgium and the Netherlands, tide mills have been utilized as well (Van der Veur and Van Wijk 1999). The technology was exported to the Americas (Newman and Holton 2006) and Australia. Apart from the Persian Gulf, where tide mills were used as well, tide mills seem to have been a European technology. The recent discovery of seventh-century tide mills in Northern Ireland and a Roman tide mill on London's Fleet River suggests that tide mills have been in use in Europe for centuries (McErlean and Crothers 2008; Spain 2002).

In order to understand a tide mill, its technical features need to be understood, including tidal range, resulting forces on the mill, and energy delivered and required for certain uses. The engineering aspect of these artifacts is intriguing, as shown by the analysis provided by Spain (2002) on the possible Roman tide mill near London. Studying such an artifact, or finding one, also brings up new questions about the context in which it functioned. The discovery of the remains of two tide mills at the site of Nendrum Monastery (Northern Ireland) has stimulated reinterpretations of earlier ideas about the development of the monastery (McErlean and Crothers 2008). Recent excavations on this site have shown that the reservoir which traditionally was perceived as a fish pond was in fact a mill pond for a tide mill. Ideas about the available material basis of the monastery, including food production and abilities to invest relatively large amounts of labor and wood in the mill, had to be discussed anew.

These analyses also make clear that a tidal mill does not mean much without a social context. Why would people be prepared to invest the considerable amounts of labor and material required to construct and maintain such a structure? Perhaps using the tide was the only option available, but it could also have been the best option accessible for certain groups. The tide mill typically operates in salt water conditions and only under certain conditions (e.g., storm swells, etc.). Keeping the mill working was a challenge, but the yields must have warranted the effort. How was the labor needed to maintain the mill organized? Who was responsible for organizing and managing this labor? A related issue is the daily operation of the mills. As the tidal sequence shifts in time, milling operation times shift as well. Occasionally, mill operators had to work during the night. Which products were made in the mill? How was the production transported to consumers or users? How far were these users located from the mill? What forces drove the industries supported by the mill?

Overall, understanding the history of a tide mill requires an analysis of the material and cultural uses and meanings of water. The tide mill is a strong symbol of the aims of this journal. Apart from the theoretical notions discussed above, one interesting feature of the tide mill is its close connection to salt water and the sea. Seas and salt are not often focused on in the field of water history. This journal clearly wants to include discourses on materiality and cultural and utilitarian value of salt water.

\section{Who will make it happen and how?}

The publication of Water History, the official journal of the International Water History Association (IWHA), symbolizes increased interest in the interdisciplinary nature of water 
research and the recognition of the importance of history to current debates about water management. Founded in 2001, IWHA has members from over 70 countries. The association seeks to encourage, promote, and foster historical understanding of the relationship between water and humankind. Problems and/or concerns in water development in the past relate directly and indirectly to contemporary issues. Drawing analogies between past and present events may yield similarities that can have a profound effect on current waterrelated decision making. The historical perspective, by providing context, the longue durée, and useful case studies, invites today's managers to think more creatively about water issues. Historical research also provides concrete examples for many of the theoretical concerns within related fields. The historian's ability to study a project from its inception to completion can inform ongoing activities.

Water History welcomes articles which examine water history from a specific disciplinary or scientific perspective, or articles that incorporate the methods of several disciplines. All articles should deal with either the broad social context of water, or seek to incorporate at least more than one disciplinary perspective. International comparisons are also very welcome. Contributions discussing methodological implications and approaches for interdisciplinary water historical research are encouraged. Given the wide range of possible topics within the field of water history, thematic issues will be published as well. Our editorial board reflects this commitment to interdisciplinarity (history, archaeology, geography, and engineering) and geographical breadth (Africa, Asia and the Pacific, Europe, and North America).

\section{This first issue}

The articles in this inaugural issue underscore several of the issues discussed above. Philippus Wester examines the hydraulic mission of the Mexican government as embodied in its hydraulic bureaucracy (hydrocracy). He argues that the centralization of water development and the creation of water overexploitation in the Lerma-Chapala Basin between 1876 and 1976 was not an unforeseen side effect, but the deliberate intent of the hydrocrats working in the basin. Every drop of water evaporating from Lake Chapala or flowing into the ocean was seen as a "loss" that needed to be captured for human uses. The Lerma-Chapala case offers a clear example of how human manipulation and hydrological realities of rivers are closely intertwined.

Kate Showers' article explores the varying plans for the world's second largest riverAfrica's Congo River. For the past hundred years, engineers and planners have sought to develop a hydropower project at Grand Inga. Situating the scheme within a continental and global political economic context, Showers shows the Grand Inga's long environmental history and suggests the project's potential environmental impact on the greater Atlantic Basin. The case provides an example of a broader historical process: as African rivers became dammed in the name of "development" during the colonial era, elites and international corporations tended to benefit at the expense of the environment. This discussion of the roles stakeholders played in water interventions, and the relationship between processes of centralization and exploitation draws these two articles together. Both also touch upon the environmental consequences these river schemes have generated.

In the issue's final article, Kate Berry explores an environment that seems to be without water. She takes us to the Kings River Valley in northern Humboldt County, Nevada. Despite the sparse peopling of the valley and its inaccessibility, there was a short time when the Kings River Valley was lauded as a triumph of industriousness and the successful 
application of new water technologies. For a brief period in the mid-twentieth century, the valley was heralded as a symbol of successful groundwater irrigation. This altered the image of the valley from that of a remote arid place to a symbol of human ability to overcome the limits of nature. The valley's history brings to light how groundwater use, technology, and regulation may be connected with the perception of place and space.

Together, the articles do illustrate how water histories connect the physical and human worlds to their specific temporal and spatial settings. In doing so, they serve as an invitation to all readers to write their stories of water. We look forward to reading and publishing them.

Open Access This article is distributed under the terms of the Creative Commons Attribution Noncommercial License which permits any noncommercial use, distribution, and reproduction in any medium, provided the original author(s) and source are credited.

\section{References}

Adams WM (1992) Wasting the rain: rivers, people and planning in Africa. University of Minnesota Press, Minnesota

Ball $\mathrm{Ph}(1999) \mathrm{H}_{2} \mathrm{O}$, a biography of water. Phoenix, London

Bankoff G (2003) Constructing vulnerability: the historical, natural and social generation of flooding in metro Manila. Disasters 27(3):224-238

Boomgaard P (ed) (2007) A world of water: rain, rivers and seas in Southeast Asian histories. KITLV Press, Leiden/NUS Press, Singapore

Charlier RH, Ménanteau L, Chaineux MCP (2004) The rise and fall of the tide mill. In: Morcos S et al (eds) Ocean sciences bridging the millennia: a spectrum of historical accounts. UNESCO Publishing, Paris \& China Ocean Press, Qingdao, pp 315-338

Collins RO (1990) The waters of the Nile: hydropolitics and the Jonglei Canal, 1900-1988. Oxford University Press, Oxford

Cooper JS (1983) Reconstructing history from ancient sources: the Lagash-Umma border conflict. Undena, Malibu

De Bruin D, Schultz B (2003) A simple start with far-reaching consequences. Irrigation Drainage 52(1):5163

Diaz HF, Morehouse BJ (eds) (2003) Climate and water: transboundary challenges in the Americas. Kluwer Academic Press, Dordrecht

Donahue J, Johnston BR (eds) (1998) Water, culture, \& power: local struggles in a global context. Island Press, Washington, DC

Gill RB (2000) Great Maya droughts: water, life, and death. University of New Mexico Press, Albuquerque, $\mathrm{NM}$

Hundley N (1992) The great thirst: Californians and water, 1770s-1990s. University of California Press, Berkeley

Lansing JS (1991) Priests and programmers: technologies of power in the engineered landscape of Bali. Princeton University Press, Princeton

Lucero LJ, Fash BW (eds) (2006) Precolumbian water management: ideology, ritual, and power. University of Arizona, Tucson

Magnusson RJ (2001) Water technology in the middle ages. Cities, monasteries and waterworks after the Roman Empire. John Hopkins University Press, Baltimore

Marcus J, Stanish C (eds) (2005) Agricultural strategies. Cotsen Institute of Archaeology, Los Angeles

McErlean T, Crothers N (2008) Harnessing the tides. The early medieval tide mills at Nendrum Monastery, Strangford Lough, Northern Ireland Archaeological Monographs No. 7, Environment and Heritage Service

Miller C (ed) (2001) Fluid arguments: five centuries of western water conflict. University of Arizona Press, Tucson, AZ

Minchinton WE (1979) Early tide mills: some problems. Technology and Culture. 20(4):777-786

Newman WA, Holton WE (2006) Boston's Back Bay: the story of America's greatest nineteenth-century landfill project. Northeastern University Press, Boston 
Pietz D (2002) Engineering the state: the Huai river and reconstruction in nationalist, China, 1927-1937. Routledge, New York

Reisner M (1986) Cadillac desert: the American west and its disappearing water. Penguin Books, New York Rortajada C (ed) (2000) Women and water management: the latin American experience. Oxford University Press, New Delhi

Scarborough VL (2003) The flow of power: ancient water systems and landscapes. School of American Research, Santa Fe

Sewell JH Jr (2005) Logics of history. Social theory and social transformation. University of Chicago Press, Chicago

Spain R (2002) A possible Roman tide mill. Kent Archaeological Society, paper 005

Steinberg T (1991) Nature incorporated: industrialization and the waters of new England. Cambridge University Press, Cambridge

Tempelhoff J (ed) (2005) African water histories: transdisciplinary discourses. North-West University, Potchefstroom, South Africa

Van Dam PJEM (2000) Sinking Peat Bogs: environmental change in Holland, 1350-1550. Environ Hist 5(4):32-45

Van den Veur WTh, Van Wijk E (1999) De getijmolens van Middelburg, Tijdschrift voor Waterstaatsgeschiedenis. pp 57-66

Ward E (2003) Border oasis: water and the political ecology of the Colorado River Delta, 1940-1975. University of Arizona Press, Tucson

Worster D (1985) Rivers of empire: water, aridity, and the growth of the American west. Oxford University Press, New York 